\title{
Ecological aspects and molecular detection of Leishmania DNA (Kinetoplastida: Trypanosomatidae) in phlebotomine sand flies (Diptera: Psychodidae) from a rural settlement in the Eastern Amazon, Brazil
}

\author{
Tiago Silva da Costa ${ }^{1,2}$ (D), Ricardo Marcelo dos Anjos Ferreira ${ }^{1}$, \\ Gabriel Silva Santos $^{3}$ (D), Manoel Daltro Garcia Júnior ${ }^{1,2}$, Camila Barbosa Pinto ${ }^{1,4}$, \\ Raimundo Nonato Picanço Souto ${ }^{1}$ \\ ${ }^{1}$ Universidade Federal do Amapá, Laboratório de Arthropoda, Macapá, AP, Brasil. \\ ${ }^{2}$ Universidade Federal do Amapá (UNIFAP), Programa de Pós-Graduação em Biodiversidade Tropical (PPGBIO), Macapá, AP, Brasil. \\ ${ }^{3}$ Universidade do Estado do Rio de Janeiro, Programa de Pós-Graduação em Ecologia e Evolução, Rio de Janeiro, RJ, Brasil. \\ ${ }^{4}$ Universidade Federal do Amapá, Curso de Ciências Biológicas, Macapá, AP, Brasil.
}

\section{A R T I C L E I N F O}

\section{Article history:}

Received 15 June 2021

Accepted 12 September 2021

Available online 08 November 2021

Associate Editor: Maria Sallum

\section{Keywords:}

Sand flies diversity

Amapá

Amazon region

PCR

\begin{abstract}
A B S T R A C T
Notifications concerning American tegumentary leishmaniasis (ATL) are increasing in the northern areas of Brazil, particularly due to the ongoing increase in human settlements inside the Amazon Forest. Notwithstanding the economical and sanitary importance of the ATL, the ecological aspects of its potential vectors, the Phlebotomine sand flies (Diptera: Psychodidae), remains largely neglected. This study aimed to investigate the diversity of the phlebotomine fauna as well as the detection of Leishmania DNA in these insects in the rural settlement Perimetral Norte, in the state of Amapá, eastern region of the Amazon, endemic region for tegumentary leishmaniasis. Sand flies were collected bimonthly from February 2018 to February 2019, using CDC light traps exposed for three consecutive nights in 10 houses of settlement residents. DNA extraction and multiplex PCR were performed to detect trypanosomatids. A total of 3,946 sandflies belonging to 37 species were collected. The most abundant species were Ty. trichopyga (Floch \& Abonnenc, 1945) (21.9\%) and Mi. rorotaensis (Floch \& Abonnenc, 1944) (16.9\%). A total of 36 positive pools were found with Leishmania DNA (Kinetoplastida: Trypanosomatidae), representing $17.9 \%$ of the total pools tested (201), those with the highest Minimum infection rates were $\mathrm{Mg}$. migonei(França, 1920) and Lu. gomezi (Nitzulescu, 1931), Leishmania DNA was also detected in Bi. flaviscutellata (Mangabeira, 1942), Ny. umbratilis (Ward \& Fraiha, 1977), Ny. anduzei (Roseboom, 1942) and Ny. antunesi (Coutinho, 1939). These data confirm the probable participation of these four species in the tegumentary leishmaniasis cycle in the eastern Amazon.
\end{abstract}

\section{Introduction}

Phlebotomine sand flies (Diptera: Psychodidae) are small dipterans of medical and veterinary relevance, as they play a role in the transmission of pathogens between human and other mammals. These insects have a wide geographic distribution and can be found on all continents except the poles (Pinto et al., 2015; Silva et al., 2020). In the Amazon region, sandflies are the natural vectors of protozoa of the genus Leishmania Ross 1903, which is the etiologic agent of American tegumentary leishmaniasis (ATL) (Galati, 2019, 2017). Among the parasitic disease occurring in humans, leishmaniasis occupy a prominent place, due to its medical and economic importance and because it represents one of the major public health problems (Brazil et al., 2015; WHO, 2010, 2021).

\footnotetext{
${ }^{*}$ Corresponding author.

E-mail: tiago_sc@hotmail.com (T. S. da Costa).
}

Phlebotomines have a great diversity of species, but not all of them have the vectorial competence to act as vectors of the protozoan Leishmania, so it is necessary to identify potential vectors through reliable techniques that can point out which species are infected and thus better understand medical epidemiology and disease entomology involved in the leishmaniasis cycle (Perez et al., 1994). Among the phlebotomine infectivity techniques, molecular identification has become one of the most used, due to its ability to identify Leishmania genetic material in the genomic DNA extracted from the phlebotomine, regardless of the amount, stage or location in the phlebotomine digestive tract (Carvalho et al., 2017; Zivdari et al., 2018). Recent research demonstrates the Polymerase Chain Reaction (PCR) as a highly accurate and important molecular technique for identification and infectivity research (Sambrook and Russel, 2012). 
In Brazil, ATL has three distinct epidemiological patterns: a) Wild: in which man becomes infected when in contact with the wild environment of primary vegetation where the enzootic cycle of leishmaniasis is taking place, b) Occupational and leisure: which it is associated with the disordered exploration of forest areas, such as clearing, road construction, hydroelectric power plants, agriculture and livestock, etc., and C) Rural and peri-urban: which is related to the colonization processes of new areas (Brasil, 2017). Part of the study effort is to try to trace the epidemiological profile that occurs in the Eastern Amazon region, that remains without much knowledge to the present day.

Despite the diversity of sand flies in the Eastern Amazon and the large number of cases of ATL, the state of Amapá continues to be one of the Amazon regions with less surveys and sampling of sand fly fauna; there are few studies carried out to date to investigate sand fly fauna and to a lesser extent number for the detection of Leishmania sp.(Forattini, 1959; Brazil et al., 2000; Souza et al., 2001; Saraiva et al., 2011; Furtado et al., 2016; Souza et al., 2017; Almeida et al., 2020; Moreno et al., 2020), and mostly with sampling efforts of a few days and in border areas.

Therefore, the development of differentiated methods such as PCR, for the identification of protozoa in vector insects becomes relevant for entomological surveys. Vector control programs, as well as the epidemiological understanding of the endemic in the state of Amapá, evidence of autochthonous transmission of the disease has been found. In this way, this study proposes the identification of the potential insect vectors of ATL in the rural settlement called "Perimetral Norte Rural Settlement”, located in Pedra Branca do Amapari Municipality, where groups of farmers live and work and in which cases of ATL have been increasingly identified in recent years (Amapá, 2019).

\section{Material and Methods}

\section{Ethic statements}

The collection of sand flies was carried out with the authorization of the Biodiversity Information and Authorization System (SISBIO) with the license Number: 62582. During the period of the study, the installation of traps and collections had the authorization and support of the residents of the settlement. The slides with the sand flies containing the identification of the collected insects were deposited in the scientific collection of the Arthropod Laboratory (ArtroLab) of the Federal University of Amapá (UNIFAP).

\section{Study area}

The study was conducted in the rural area of the state of Amapá, northern Brazil, in the Municipality called Pedra Branca do Amapari where the Perimetral Rural Settlement Project is located (01 ${ }^{\circ} 05^{\prime} 13.1^{\prime \prime} \mathrm{N} ; 52^{\circ}$ 28 '34.4” W) (Fig.1). The settlement was created on 04/01/1987, having an area of 34,000 (ha) with 398 settled families (Filocreão and Silva, 2016), and is located $70 \mathrm{~km}$ from the seat of the Municipality and $244 \mathrm{~km}$ from the city of Macapá, capital of the State of Amapá. The climate in the state of Amapá is humid tropical, with its classification Am (Köppen classification), with an average temperature of $26.6^{\circ} \mathrm{C}$, and an average annual rainfall of $3322 \mathrm{~mm}$, subject to a wide seasonal variation (Tavares, 2014).

Historically, Pedra Branca do Amapari Municipality has its origins linked to the exploration of gold by the Samaracás, a primitive indigenous tribe of French Guiana and North of Amapá. The site was chosen for study because of its forest area that is home to a great entomofaunistic

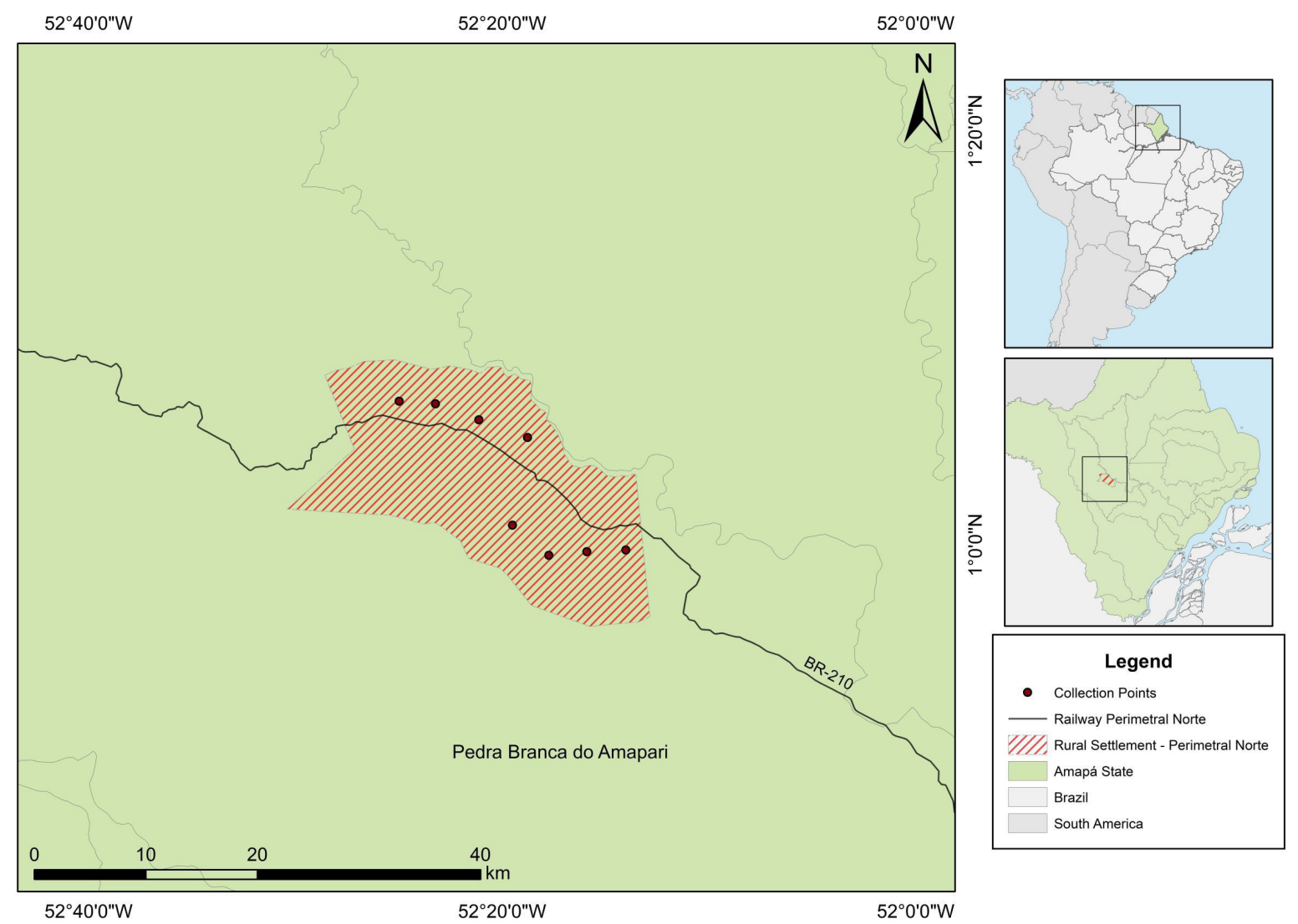

Figure 1 Map of the study area and sand flies collection points, Perimetral Norte Rural Seattlement, Pedra Branca Municipality, Amapá State, Brazil. 
diversity, as it is a type of exploitation of land use that is configured in human communities that have their own dynamics between their homes and the surrounding forest, according to data from the Health Surveillance Center of the state of Amapá, Pedra Branca do Amapari Municipality has presented in the last five years an endemic focus for ATL, with 528 reported cases of the endemic in the city (Brasil, 2021).

\section{Collection and identification of Phlebotominae Sand Flies.}

The sand flies were collected during the period from February / 2018 to February / 2019. Every two months, during three consecutive nights from 5:00 pm. to 7:00 am., $40 \mathrm{CDC}$ light traps (Center for Disease Control and Prevention) were arranged in a line towards the nearest forest edge from 10 houses used as reference at each fixed collection point: Intradomicile (Id), Peridomicile (Pd), and from the edge of the forest: area 100m (F100: transition area between occupied area and forest) and 400m (F400: forest area). The houses chosen were those that were close to the forest around the settlement, and that had chicken coops and pig breeding, an aspect that favours the presence of sand flies.

The collected insects were taken to the Arthropoda Laboratory (Arthrolab) at the Federal University of Amapá (UNIFAP) for selection by sex, clarification, processing and dissection. The specimens were dissected by removing the head and the last three segments of the abdomen for mounting on slides of glass and Berlese liquid. The rest of the specimens' bodies were stored in microtubes with ethanol in a $-20^{\circ} \mathrm{C}$ freezer for subsequent DNA extraction.

Species identification was carried out using external morphological characters down to the species level, using the classification developed by Galati (Galati, 2003, 2019), and following the abbreviation of the genera proposed by Marcondes (Marcondes, 2007).

\section{Extraction and detection of Leishmania $D N A$}

The samples of the specimens preserved in ethanol were subjected to extraction in a pool of 10 females of the same species, collection point and date. Females with eggs and blood were excluded to avoid the possible detection of Leishmania DNA in undigested blood.

The DNA extraction was performed using Gentra Puregene ${ }^{\circledR}$ Genomic DNA Kit (QIAGEN, USA), following the manufacturer's instructions. For the detection of Leishmania DNA, a multiplex polymerase chain reaction $(\mathrm{PCR})$ was used, firstly a mini-circle of $\mathrm{kDNA}(\cong 116 \mathrm{bp}$ ) for identification of the Leishmania genus, using the primers: $5^{\prime} G G G(G$ / T) AGGGGCGTTCT $(G / C) C G A A 3$ ' and 5' $(G / C)(G / C)(G / C)(A / T)$ CTAT (A / T) TTAC CAACCCC3 '(Reale et al., 1999), and to confirm the quality of the extracted DNA, a second target was used for sand flies: LCO1490 (5'-GGTCAA CAA ATC ATA AAG ATA TTGG-3') and HCO2198 (5'TAA ACT TCA GGG TGA CCAAAA AATCA3') (Folmer et al., 1994). The PCR had the following protocol performed in two stages: the reaction mixture was made by adding $5 \mu \mathrm{L}$ of the DNA extraction reaction, $0.15 \mu \mathrm{L}$ of each primer $(0.4 \mu \mathrm{M}), 0.75 \mu \mathrm{L}$ of $\mathrm{MgCl} 2(3.5 \mu \mathrm{M}), 0.5 \mu \mathrm{L}$ of dNTPs $(0.2 \mathrm{mM}), 1 \mathrm{U}$ Taq polymerase and Buffer $1 \times$, for a total volume of $25 \mu \mathrm{l}$. The multiplex reaction was performed: $1^{\text {st }}$ phase - initial denaturation at $94{ }^{\circ} \mathrm{C}$ for five minutes, followed by 30 replicates of: denaturation at $94{ }^{\circ} \mathrm{C}$ for 30 seconds, annealing at $60{ }^{\circ} \mathrm{C}$ for 30 seconds and extension at $72{ }^{\circ} \mathrm{C}$ for 30 seconds; 2 nd phase: initial denaturation at $94{ }^{\circ} \mathrm{C}$ for five minutes, followed by 30 replicates of: denaturation at $94{ }^{\circ} \mathrm{C}$ for 30 seconds, annealing at $65{ }^{\circ} \mathrm{C}$ for 30 seconds and extension of $72{ }^{\circ} \mathrm{C}$ for 30 seconds. The final extension was $72{ }^{\circ} \mathrm{C}$ for five minutes in both reactions. The amplicons were visualized on a $2 \%$ agarose gel stained with ethidium bromide, and for comparison a standard molecular weight of 100 bp DNA Step Ladder.

\section{Data Analysis}

The quantification of the collected specimens was expressed through absolute abundance and relative abundance. To assess the most abundant species among the collection sites, the Stantardized Index of Species Abundance (SISA) (Roberts and Hsi, 1979) was used, in which values $\geq 1$ is related to the most abundant species. The distribution of species in the study period was calculated using the Constancy Index (Silveira Neto et al., 1976), which classifies the species as constant (present in more than $50 \%$ of collections), accessory (present from 25 to $50 \%$ of collections), or accidental (present in less than $25 \%$ of collections). Leishmania DNA positive pools were evaluated using the Minimum Infection Rate (MIR) (Resadore et al., 2017) which was calculated using the formula: number of positive pools x 100 / total number of females in pool.

To compare the species richness, diversity and distribution along the Intradomicile-Forest gradient, the Shannon $\left(\mathrm{H}^{\prime}\right)$ index and species evenness by the Pielou's index for each of the four sampled areas. The indices were calculated using the Vegan 2.5.5 package (Oksanen et al., 2017). The observed species richness, as well as the estimated richness by the Bootstrap method with 1000 randomizations (Vegan 2.5.5) were also obtained and compared. All comparisons were performed using the Analysis of Variance test (ANOVA) followed by peer-to-peer comparison by Tukey's post-hoc test. All analyzes were used in software R 3.6.0 (R Core Team).

\section{RESULTS}

A total of 3,946 individuals were collected, 1,229 males and 2,717 females, belonging to 37 species and 15 genera: Psychodopygus (PS. 7 spp.), Evandromyia(Ev. 6 spp.), Nyssomyia(Ny. 4 spp.), Psathyromyia (Pa. 4 spp.), Trichophoromyia (Th. 3 spp.), Migonemyia (Mg. 2 spp.), Sciopemyia (Sc. 2 spp.), Vianamyia (Vi. 2 spp.), Bichromomyia (Bi. $1 \mathrm{sp}$. ), Brumptomyia (Br. $1 \mathrm{sp}$. ), Lutzomyia (Lu. 1 sp.), Micropygomyia (Mi. 1 sp.), Pintomyia (Pi. 1 sp.), Pressatia (Pr. 1 sp), Trichopygomyia (Ty. 1 sp.) (Table 1$)$.

The most abundant species were Ty. trichopyga (21.9\%, 3rd rank SISA), followed by Mi. rorotaensis (16.9\%, 1st rank SISA), Ny. umbratilis (11.5\%, 2nd rank SISA), Sc. sordellii (Shannon \& Del Ponte, 1927) $(7.8 \%$, 4th rank SISA), Ps. davisi (Root, 1934) (6.0\%, 6th rank SISA). The male/ female ratio was 0.45 , with $31.1 \%$ males and $68.9 \%$ females.

The most abundant environment was the $\mathrm{F} 400 \mathrm{~m}$ forest environment with 2,150 (54.4\%) specimens and 37 species were collected. The predominant species were Ty. trichopyga(485 specimens, 22.5\%), Mi. rorotaensis (398 specimens, 18.5\%) and Ny. umbratilis (256 specimens, $11.9 \%$ ). In the F100m environment, 1,301 (32.9\%) specimens and 35 species were collected, with the predominance of Ty. trichopyga (352 specimens, 27\%), Mi. rorotaensis (192 specimens, 14.7\%) and Ny. umbratilis (137 specimens, 11.9\%). In the peridomicile, 263 (6.6\%) specimens and 23 species were collected, predominantly Sc. sordellii (60 specimens, 22.8\%), Ny. umbratilis (46 specimens, 17.4\%) and $M i$. rorotaensis (23 specimens, $8.7 \%$ ). In the Intradomicile environment, a total of $232(5.8 \%)$ specimens and 13 species, Sc. sordellii $(95$ specimens, 40.9\%) was the most abundant, followed by Mi. rorotaensis ( 56 specimens, $24.1 \%$ ) and Ty. trichopyga (21 specimens, 9\%) (Table 1).

The collection site with the highest diversity index was F400 ( $\mathrm{H}^{\prime}=2.73$ ), followed by peridomicile $\left(H^{\prime}=2.67\right)$. The analysis of variance showed that, in general, the diversity indices differ significantly between the sampled environments $(\mathrm{F}=448.2, \mathrm{df}=3, \mathrm{P}<0.001)$. The only exception, according to Tukey's post-hoc test, was between the areas of Peridomicile and F400 (Tukey $=0.411$ ). In the comparison between the diversity index applying the Analysis of Variance followed by the Tukey test between 
Table 1

Species of sandflies from Perimetral Norte Settlement, Pedra Branca Municipality, Amapá State, Brazil, collected with CDC light traps from February 2018 to February 2019.

\begin{tabular}{|c|c|c|c|c|c|c|c|c|c|c|c|c|c|}
\hline \multirow{3}{*}{$\begin{array}{c}\text { Species } \\
\begin{array}{l}\text { Ty. trichopyga Floch \& } \\
\text { Abonnenc, } 1945\end{array}\end{array}$} & \multirow{2}{*}{\multicolumn{2}{|c|}{$\frac{\mathrm{ID}}{\mathrm{M} \delta \mathrm{F}}$}} & \multirow{2}{*}{\multicolumn{2}{|c|}{$\frac{\mathrm{PD}}{\mathrm{M} \circlearrowleft \mathrm{F}_{+}}$}} & \multirow{2}{*}{\multicolumn{2}{|c|}{$\begin{array}{c}100 \mathrm{M} \\
\mathrm{M} \delta \mathrm{F} \odot\end{array}$}} & \multirow{2}{*}{\multicolumn{2}{|c|}{$\begin{array}{c}400 \mathrm{M} \\
\mathrm{M}^{\wedge} \mathrm{F}_{+}\end{array}$}} & \multirow{3}{*}{$\begin{array}{c}\text { Total } \\
868\end{array}$} & \multirow{3}{*}{$\begin{array}{c}\% \\
21.9\end{array}$} & \multirow{3}{*}{$\begin{array}{c}\text { Ratio M/F } \\
0.64\end{array}$} & \multirow{3}{*}{$\begin{array}{r}\text { SISA } \\
0.9\end{array}$} & \multirow{3}{*}{ Rank } \\
\hline & & & & & & & & & & & & & \\
\hline & 8 & 13 & 3 & 7 & 150 & 202 & 180 & 305 & & & & & \\
\hline $\begin{array}{l}\text { Mi. rorotaensis Floch } \\
\text { \& Abonnenc, } 1944\end{array}$ & 7 & 49 & 5 & 18 & 37 & 155 & 55 & 343 & 669 & 16.9 & 0.18 & 1.0 & 1 \\
\hline $\begin{array}{l}\text { Ny. umbratilis Ward } \\
\text { \& Fraiha, } 1977\end{array}$ & 5 & 11 & 34 & 12 & 35 & 102 & 46 & 210 & 455 & 11.5 & 0.35 & 1.0 & 2 \\
\hline $\begin{array}{l}\text { Sc. sordellii Shannon } \\
\text { \& Del Ponte, } 1927\end{array}$ & 12 & 83 & 5 & 55 & 14 & 26 & 36 & 78 & 309 & 7.8 & 0.27 & 0.9 & 4 \\
\hline Ps. davisi Root, 1934 & 1 & 3 & 2 & 9 & 16 & 85 & 20 & 102 & 238 & 6.0 & 0.19 & 0.8 & 6 \\
\hline $\begin{array}{c}\text { Th. brachypiga } \\
\text { Mangabeira, } 1942\end{array}$ & - & - & - & - & 65 & - & 112 & - & 177 & 4.4 & - & 0.8 & 8 \\
\hline $\begin{array}{c}\text { Ny. anduzei } \\
\text { Rozeboom, } 1942\end{array}$ & 2 & 10 & 1 & 6 & 6 & 77 & 7 & 36 & 145 & 3.6 & 0.12 & 0.8 & 5 \\
\hline $\begin{array}{c}\text { Ny. yuilli pajoti } \\
\text { Abonnenc, Léger\& } \\
\text { Fauran, } 1979\end{array}$ & - & - & - & 10 & 10 & 35 & 22 & 62 & 139 & 3.5 & 0.29 & 0.5 & 17 \\
\hline $\begin{array}{c}\text { Br. pintoi Costa Lima, } \\
1932\end{array}$ & - & - & 5 & 10 & 8 & 27 & 28 & 49 & 127 & 3.2 & 0.47 & 0.7 & 10 \\
\hline $\begin{array}{c}\text { Ps. geniculatus } \\
\text { Mangabeira, } 1941\end{array}$ & - & - & 8 & 3 & 4 & 36 & 15 & 58 & 124 & 3.1 & 0.27 & 0.8 & 7 \\
\hline $\begin{array}{c}\text { Th. ubiquitalis } \\
\text { Mangabeira, } 1942\end{array}$ & - & - & - & - & 22 & 13 & 35 & 24 & 94 & 2.3 & 1.54 & 0.7 & 9 \\
\hline $\begin{array}{l}\text { Bi. flaviscutellata } \\
\text { Mangabeira, } 1942\end{array}$ & - & - & 5 & 11 & 17 & 33 & 11 & 8 & 85 & 2.1 & 0.63 & 0.6 & 13 \\
\hline $\begin{array}{c}\text { Ev. monstruosa } \\
\text { Martins, Falcão \& } \\
\text { Silva, } 1965\end{array}$ & 1 & 3 & 2 & 6 & 10 & 2 & 15 & 31 & 70 & 1.7 & 0.66 & 0.6 & 12 \\
\hline $\begin{array}{c}\text { Ps. sq. squamiventris } \\
\text { Floch \& Abonnenc, } \\
1944\end{array}$ & 2 & 3 & 2 & 8 & 5 & 1 & 12 & 32 & 65 & 1.6 & 0.47 & 0.3 & 21 \\
\hline $\begin{array}{c}\text { Ev. brachyphalla } \\
\text { Mangabeira, } 1941\end{array}$ & - & - & - & 2 & 6 & 10 & 15 & 21 & 54 & 1.3 & 0.63 & 0.5 & 15 \\
\hline $\begin{array}{c}\text { Vi. tuberculata } \\
\text { Mangabeira, } 1941\end{array}$ & - & - & 2 & - & 5 & - & 19 & 22 & 48 & 1.2 & 1.18 & 0.5 & 16 \\
\hline $\begin{array}{l}\text { Pa. aragaoi Costa } \\
\text { Lima, } 1932\end{array}$ & - & 1 & 3 & - & 6 & 9 & 6 & 12 & 37 & 0.9 & 0.68 & 0.7 & 11 \\
\hline $\begin{array}{c}\text { Vi. furcata } \\
\text { Mangabeira, } 1941\end{array}$ & 2 & - & 1 & 2 & 2 & 5 & 5 & 12 & 29 & 0.7 & 0.52 & 0.6 & 14 \\
\hline $\begin{array}{l}\text { Ev. andersoni Le Pont } \\
\text { \& Desjeux, } 1988\end{array}$ & - & & 2 & 4 & 3 & 6 & 8 & 3 & 26 & 0.6 & 1 & 0.3 & 22 \\
\hline $\begin{array}{c}\text { Ny. antunesi } \\
\text { Coutinho, } 1939\end{array}$ & - & 6 & - & 9 & - & 6 & - & 4 & 25 & 0.6 & - & 0.4 & 19 \\
\hline $\begin{array}{c}\text { Ev. infraspinosa } \\
\text { Mangabeira, } 1941\end{array}$ & - & - & - & - & 3 & 3 & 4 & 9 & 19 & 0.4 & 0.58 & 0.4 & 20 \\
\hline $\begin{array}{l}\text { Sc. fluviatilis Floch \& } \\
\text { Abonnenc, } 1944\end{array}$ & - & & - & - & - & 6 & - & 10 & 16 & 0.4 & - & 0.5 & 18 \\
\hline $\begin{array}{c}\text { Pa. dreisbachi Causey } \\
\text { \& Damasceno, } 1945\end{array}$ & 3 & 5 & - & 2 & 1 & - & 4 & - & 15 & 0.3 & 1.14 & 0.3 & 24 \\
\hline $\begin{array}{l}\text { Ps. hirsutus Causey \& } \\
\text { Damasceno, } 1945\end{array}$ & - & - & - & 2 & - & 3 & - & 7 & 12 & 0.3 & 0 & 0.2 & 28 \\
\hline $\begin{array}{c}\text { Th. depaquitiGantier, } \\
\text { Gaborit \& Rabarison, } \\
2006\end{array}$ & - & - & - & - & - & 5 & 7 & - & 12 & 0.3 & 1.4 & 0.3 & 23 \\
\hline $\begin{array}{c}\text { Ps. paraensis Costa } \\
\text { Lima, } 1941\end{array}$ & - & - & - & 2 & 1 & 5 & - & 3 & 11 & 0.2 & 0.1 & 0.2 & 27 \\
\hline $\begin{array}{c}\text { Ev. pinotti } \\
\text { Damasceno \& Arouck, } \\
1956\end{array}$ & - & - & - & - & - & 3 & 6 & - & 9 & 0.2 & - & 0.3 & 25 \\
\hline $\begin{array}{c}\text { Lu. gomezi } \\
\text { Nitzulescu, } 1931\end{array}$ & - & - & - & - & 1 & 3 & 3 & 2 & 9 & 0.2 & 0.8 & 0.2 & 32 \\
\hline $\begin{array}{c}\text { Mg. migonei França, } \\
1920\end{array}$ & - & - & - & - & 2 & 3 & 2 & 2 & 9 & 0.2 & 0.8 & 0.3 & 26 \\
\hline $\begin{array}{l}\text { Ps. corossoniensis Le } \\
\text { Pont \& Pajot, } 1978\end{array}$ & - & - & - & - & - & 2 & - & 7 & 9 & 0.2 & - & 0.2 & 31 \\
\hline $\begin{array}{l}\text { Ev. bacula Martins, } \\
\text { Falcão \& Silva, } 1965\end{array}$ & - & - & - & - & - & 3 & - & 5 & 8 & 0.2 & - & 0.2 & 29 \\
\hline $\begin{array}{c}\text { Mg. bursiformis } \\
\text { Martins, Falcão \& } \\
\text { Silva, } 1965\end{array}$ & - & - & - & - & - & 2 & - & 6 & 8 & 0.2 & - & 0.1 & 33 \\
\hline
\end{tabular}

Abbreviations: ID intradomicile, PD peridomicile, F100m forest 100m from edge, F400m forest from edge, M male, Ffemale, SISA Standardized Index of Species Abundance. 
Table 1

Continued...

\begin{tabular}{|c|c|c|c|c|c|c|c|c|c|c|c|c|c|}
\hline \multirow{3}{*}{$\begin{array}{c}\text { Species } \\
\begin{array}{c}\text { Pa. inflata Floch \& } \\
\text { Abonnenc, } 1944\end{array}\end{array}$} & \multirow{2}{*}{\multicolumn{2}{|c|}{$\frac{\mathrm{ID}}{\mathrm{M} \mathrm{F}^{\curvearrowright}}$}} & \multirow{2}{*}{\multicolumn{2}{|c|}{$\frac{\mathrm{PD}}{\mathrm{M} \delta \mathrm{F}_{+}}$}} & \multirow{2}{*}{\multicolumn{2}{|c|}{$\frac{100 \mathrm{M}}{\mathrm{M} \curvearrowright \mathrm{F} \odot}$}} & \multirow{2}{*}{\multicolumn{2}{|c|}{$\begin{array}{c}400 \mathrm{M} \\
\mathrm{M} \lesssim \mathrm{F}_{+}\end{array}$}} & \multirow{3}{*}{$\begin{array}{c}\text { Total } \\
8\end{array}$} & \multirow{3}{*}{$\begin{array}{c}\% \\
0.2\end{array}$} & \multirow{3}{*}{$\begin{array}{c}\text { Ratio } \mathrm{M} / \mathrm{F} \\
1.66\end{array}$} & \multirow{3}{*}{$\begin{array}{c}\text { SISA } \\
0.2\end{array}$} & \multirow{3}{*}{$\begin{array}{r}\text { Rank } \\
30\end{array}$} \\
\hline & & & & & & & & & & & & & \\
\hline & 2 & - & - & 3 & 2 & - & 1 & 0 & & & & & \\
\hline $\begin{array}{l}\text { Pa. Iutziana Costa } \\
\text { Lima, } 1932\end{array}$ & - & - & - & 2 & - & 1 & 2 & - & 5 & 0.1 & 0.66 & 0.1 & 34 \\
\hline $\begin{array}{c}\text { Pi. damascenoi } \\
\text { Mangabeira, } 1941\end{array}$ & - & - & - & - & - & - & - & 5 & 5 & 0.1 & - & 0.0 & 35 \\
\hline $\begin{array}{c}\text { Ps. sq. maripaensis } \\
\text { Floch \& Abonnenc, } \\
\qquad 1946\end{array}$ & - & - & - & - & - & 1 & - & 3 & 4 & 0.1 & - & 0.0 & 36 \\
\hline $\begin{array}{c}\text { Pr. trispinosa } \\
\text { Mangabeira, } 1942\end{array}$ & - & - & - & - & - & - & - & 3 & 3 & 0.0 & - & 0.0 & 37 \\
\hline Total & 45 & 187 & 80 & 183 & 431 & 870 & 673 & 1477 & 3946 & 100 & 0.45 & & \\
\hline
\end{tabular}

Abbreviations: ID intradomicile, PD peridomicile, F100m forest 100m from edge, F400m forest from edge, Mmale, Ffemale, SISA Standardized Index of Species Abundance.

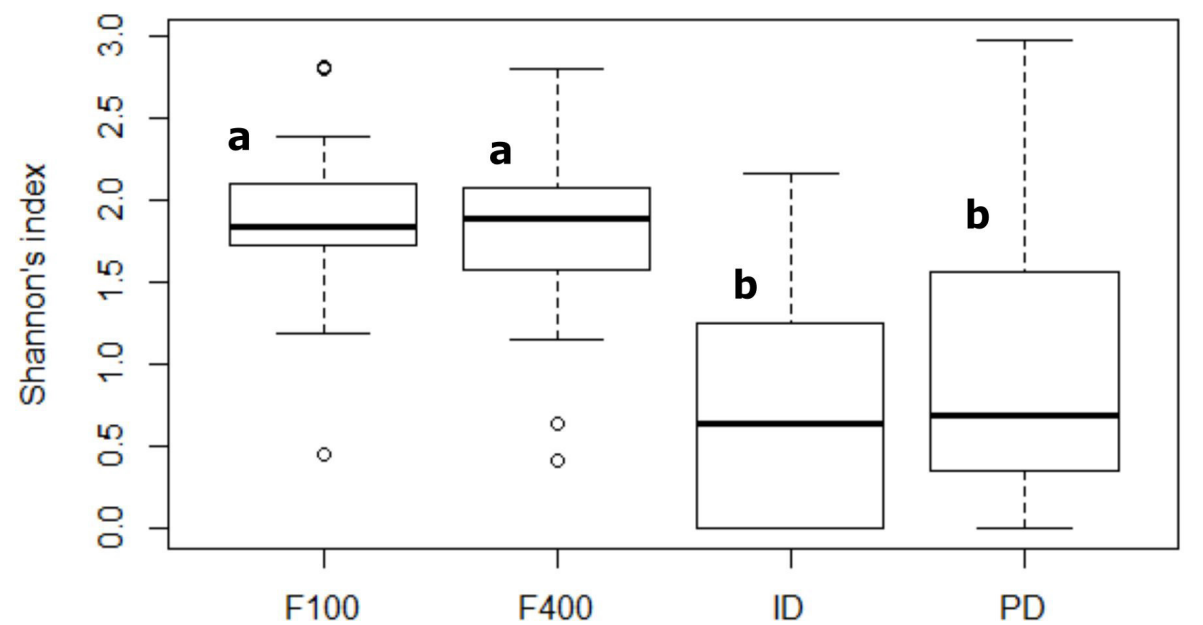

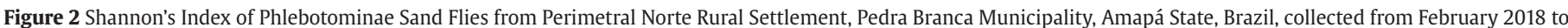

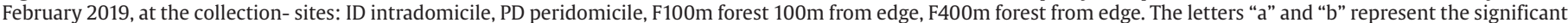
difference.

all ecotopes there was a significant difference $(\mathrm{P}=0.0000046)$, between the closest collection points there was no significant difference $\mathrm{F} 400$ and F100 ( $P=0$.0009), and Pd and Id $(P=0.0007)$, already between Id and F100 ( $\mathrm{P}=0.000058), \mathrm{Pd}$ and F100 ( $\mathrm{P}=0.00025)$, Id and F400 ( $\mathrm{P}=$ $0.000392), P d$ and F400 ( $P=0.001356)$ there was a significant difference (Fig.2). The collection area with the highest Pielou index was in the F400 forest area $(\mathrm{J}=0.89)$, with a small difference between the Pd ( $=0.88)$ and the F100 forest area $(\mathrm{J}=0.87)$, and the smallest was the Intradomicile $(\mathrm{J}=0.61)$.

The comparison between the mean abundances among all sand fly collection sites was significant $(F=5129.8, d f=3, P<0.001)$. In the comparison between the collection sites, there was a significant difference between Intradomicile and F100m ( $\mathrm{P}<0.001$ ), Peridomicile and F100 ( $\mathrm{P}<0.001)$, Intradomicile and F400 ( $<<0.001)$ and Peridomicile and F400 ( $\mathrm{P}<0.001$ ) (Fig.3). The similarity was greater between the collection areas F100 and F400 (forest areas) and Id and Pd (domestic areas), and less between Id and $\mathrm{F} 400 \mathrm{~m}$.

Leishmania DNA was found in 37 of the 211 pools of females analyzed (infection rate: 1.75\%), in the four collection environments positive samples belonging to 14 species of sand flies were found: Bi. flaviscutellata, Ev. monstruosa (Martins, Falcão \& Silva, 1965), Lu. gomezi, Mg. migonei, Ny. anduzei, Ny. antunesi, Ny. umbratilis, Pa. aragaoi (Costa Lima, 1932), Pa. dreisbachi (Causey \& Damasceno, 1945), Ps. corossoniensis (Le Pont \& Pajot, 1978), Ps. davisi, Ps. hirsutus
(Causey \& Damasceno, 1945), Ps. sq. squamiventris(Floch \& Abonnenc, 1944) and Sc. sordellii (Table 2).

Suspected or proven vector species of the protozoan Leishmania spp. Ny. umbratilis, Ny. anduzei, Ny. antunesi, Ps. squamiventris squamiventris were found in all collection areas (Pd, Id, F100 and F400), however the only species classified as Constant in the Contancy Index (CI) (Table 3) was Ny. umbratilis. The species Bi. flaviscutellata, Lu. gomezi and Mg. migonei were not found in the intradomicile (Id) and their classification in the CI was Acessory, Acidental and Acidental respectively.

\section{Discussion}

In the Amazon region, advances in changes in the dynamics of land use by man, such as the construction of roads, the establishment of settlements and the advancement of agricultural activities, have brought consequences such as deforestation, loss of biodiversity and adaptation of vectors to peridomicile environments (Rosário et al., 2017; Tadei et al., 2017; Ávila et al., 2018) and the increase in human ATL cases registered in northern Brazil demonstrate a possible collaboration of this process of adaptation of the leishmaniasis cycle vectors (Silva and Muniz, 2009). The results of our study demonstrated a high diversity of the phlebotomine fauna and a structuring of this community in the intradomicile - forest gradient. In addition, our results also demonstrate 


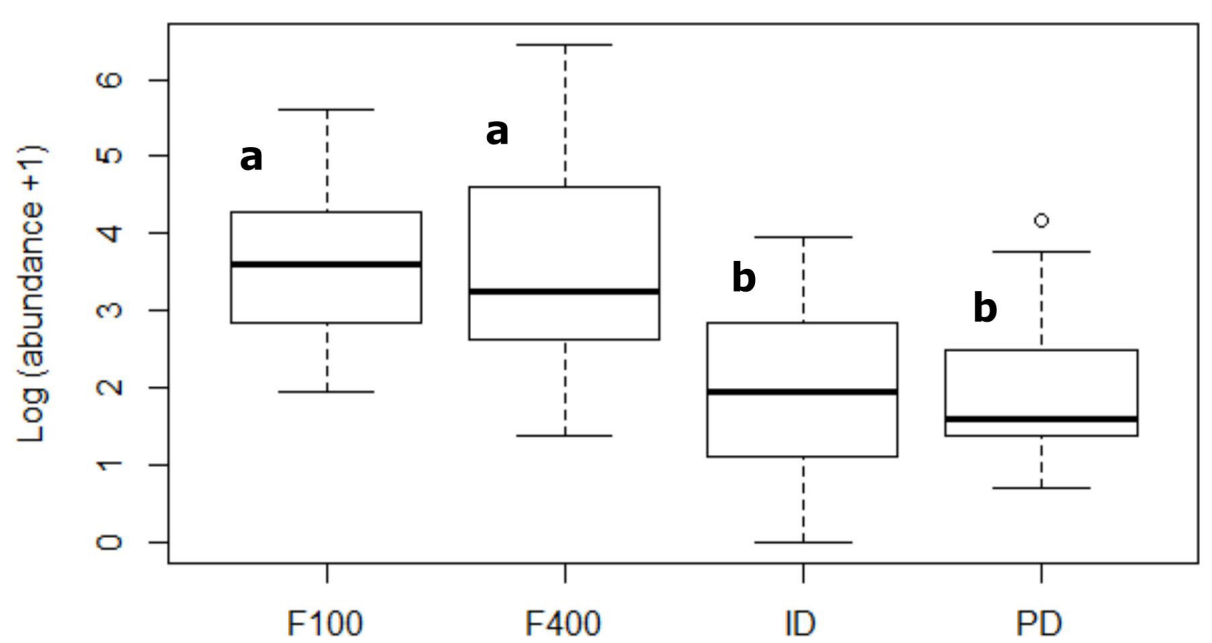

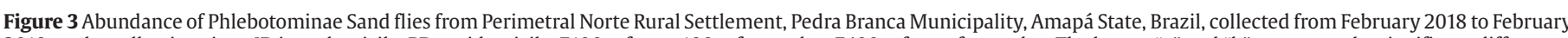

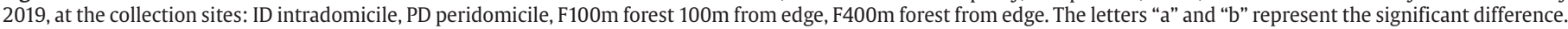

Table 2

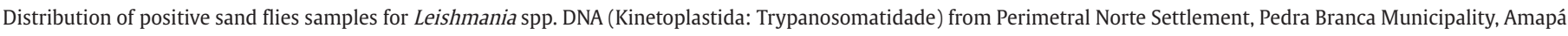
State, Brazil, collected with CDC light traps from February 2018 to February 2019, according to collection site.

\begin{tabular}{|c|c|c|c|c|c|c|}
\hline \multirow{2}{*}{ Species } & \multicolumn{4}{|c|}{ Positive pools } & \multirow{2}{*}{$\begin{array}{c}\text { Total of pools by } \\
\text { examined }\end{array}$} & \multirow{2}{*}{$\begin{array}{l}\text { Minimum infection } \\
\text { rate }\end{array}$} \\
\hline & ID & PD & $\mathrm{F} 100 \mathrm{~m}$ & $\mathrm{~F} 400 \mathrm{~m}$ & & \\
\hline Bi. flaviscutellata* & - & 1 & 1 & 2 & 5 & 10 \\
\hline Ev. monstruosa & - & - & 2 & 1 & 5 & 7.3 \\
\hline Lu. gomezi & - & - & - & 1 & 2 & 20 \\
\hline Mg. migonei* & - & 1 & - & 1 & 3 & 23 \\
\hline Ny. anduzei* & - & 3 & - & 4 & 14 & 5.4 \\
\hline Ny. antunesi* & - & 1 & - & 1 & 4 & 10.5 \\
\hline Ny. umbratilis* & 1 & - & - & 2 & 30 & 1 \\
\hline Pa. aragaoi & - & 1 & - & - & 3 & 5 \\
\hline Pa. dreisbachi & - & - & 1 & - & 2 & 14.2 \\
\hline Ps. corossoniensis & - & - & - & 1 & 2 & 12.5 \\
\hline Ps. davisi* & 1 & - & 1 & 2 & 20 & 2.1 \\
\hline Ps. hirsutus* & - & - & 1 & 1 & 3 & 18.1 \\
\hline Ps. sq. squamiventris* & - & - & - & 2 & 4 & 5 \\
\hline Sc. sordellii & 1 & - & - & 2 & 23 & 1.31 \\
\hline
\end{tabular}

* Species that are proven vectors or suspected.

high rates of infection by Leishmania spp. in sand flies. In contrast to these results, only a portion of less abundant species were found to be active vectors in the region, except for $\mathrm{Ny}$. umbratilis that in addition to being found infected with Leishmania spp. was the only species that obtained Constant status in the Constancy Index, as well as a marked concentration of these potential vectors in forest environments and their immediate surroundings. These results highlight the wild cycle of the disease, which is mostly associated with the entry of man into the wild environment where the enzootic cycle of leishmaniasis is taking place. Below we detail other important aspects for the knowledge of the ecological aspects of sand flies and the epidemiological of leishmaniasis in the eastern region of the Amazon.

In our study, $61.7 \%(\mathrm{~N}=37)$ of all species registered in the state of Amapá, eastern Amazon ( $\mathrm{N}=60$ ) were identified (Souza et al., 2017; Galati, 2018). Of these, 24.3\% ( $\mathrm{N}=9$ ) are considered suspicious or proven vectors for ATL in Brazil, some of which are Ny. umbratilis and Ps. davisi - recognized ATL vectors in the Amazon region (Brazil et al., 2015), part of the six most abundant species in the present study. Despite this, the infection rate values among $N y$. umbratilis and Ps. davisi were two of the lowest infectivity rates recorded in the analysis.

The Minimum Infection Rate (MIR) of the sand flies studied was $1.75 \%$, a rate much higher than that of studies conducted in the Amazon
Table 3

Constancy Index $(\mathrm{CI})$ for species suspected or incriminated vectors from Perimetral Norte Settlement, Pedra Branca Municipality, Amapá State, Brazil, collected with CDC light traps from February 2018 to February 2019.

\begin{tabular}{ccc}
\hline Suspected or proven vectors & Constancy Index & Status \\
\hline Bichromomyia & 38.75 & Acessory \\
flaviscutellata & 5 & Acidental \\
Migonemyia gomezi & 5 & Acidental \\
Nyssomyia anduzei & 42.5 & Acessory \\
Nyssomyia antunesi & 12.6 & Acidental \\
Nyssomyia umbratilis & 81.25 & Constant \\
Psychodopygus davisi & 35 & Acessory \\
Psychodopygus hirsutus & 10 & Acidental \\
Psychodopygus paraensis & 7.5 & Acidental \\
Psychodopygus sq. & 27.5 & Acessory \\
squamiventris & &
\end{tabular}

region as in Rondônia (0.23\%) (Resadore et al., 2017) and (0.28\%) (Resadore et al., 2019), Amazonas (0.83\%) (Pereira Júnior et al., 2015) and Acre $(0.99 \%)$ (Teles et al., 2016), in contrast in comparison with studies carried out in the border region in the Colombian Amazon the 
index was lower (4.75\%) (Trujillo et al., 2013). High rates of infectivity demonstrate the ability of vectors to maintain the leishmaniasis cycle in the region, which directly affects the number of cases of ATL in the Perimetral Norte rural settlement region that has remained on the rise for the past five years (Amapá, 2019). The detection of Leishmania DNA in sand flies that are not considered to be of medical importance does not necessarily indicate that these species are part of the ATL cycle in human cases but demonstrates that protozoa are circulating in all environments in which samples were collected in the rural Settlement.

In our findings, Lu. gomezi obtained the highest MIR (20\%), the species has a wide geographical distribution that encompasses the entire Amazon region including countries bordering Brazil such as Colombia, Venezuela, Bolivia, and French Guiana (Trujillo et al., 2013; Valderrama et al., 2014). The high MIR and the wide geographic distribution of Lu. gomezi point to this species as a potential vector of high epidemiological importance although it is often considered the opposite (Brasil, 2017). In Panama, this species is considered one of the main vectors of Leishmania (V.) panamensis (Lainson \& Shaw, 1972), the main cause of cases of ATL (Valderrama et al., 2014), which reinforces the results found in this study, however it is not considered a vector with epidemiological importance for ATL in Brazil (Brasil, 2017). Thus, even at low densities, as recorded here, our results point to a possible importance and greater epidemiological attention for future studies.

In our analysis, Ps. hirsutus had the second highest rate of infectivity (18.1\%), this species has distribution throughout the Amazon region and is considered a suspected vector of Leishmania in the Eastern Amazon as it has already been found infected with Leishmania (V.) naiffi (Lainson \& Shaw, 1989) in the state of Pará (Souza et al., 2016) and Rondônia (Gil et al., 2003). The use of molecular techniques with greater accuracy, such as DNA sequencing, would be alternatives for the study of infectivity to point out which species of Leishmania are circulating in the state of Amapá.

The abundance, richness and composition of the species in the forest area, represented by F100 and F400, were those that registered the greatest richness and abundance in our study, the finding demonstrates that the species of phlebotomine fauna has a preference for areas with greater vegetation cover and with less anthropic action, the data of the present study are corroborated by others conducted in Amapá (Souza et al., 2001; Saraiva et al., 2011; Souza et al., 2017) and in the Amazon region (Chagas et al., 2018; Pereira Júnior et al., 2019). In F400 the greatest diversity was found with a Shannon index ( $\mathrm{H}$ ') of 2.62 , while $F 100$ presented a lower index $\left(H^{\prime}=2.55\right)$ but very similar to peridomicile $(H '=2.60)$. The intradomicile showed the lowest diversity $(\mathrm{H} '=1.80)$ This is because the predominance of Mi. rorotaensis and Sc. sordellii in the area influence the decrease in the diversity index. The lower richness found in the intradomicile shows that there are still few species domiciled in the region.

The most abundant species found in the current study were $T y$. trichopyga, Mi. rorotaensis, Ny. umbratilis, Sc. sordellii, PS. davisi and Th. brachypyga (Mangabeira, 1942). Trichopygomyia trichopyga was also found as the most abundant species in a study carried out in a rural settlement in central Amazon (Chagas et al., 2018). Among the six species with greater abundance, the species $N y$. umbratilis and PS. davisi have already been found infected with Leishmania sp. in a study conducted in the eastern Amazon region (Souza et al., 2017)

The Ny. umbratilis species is considered one of the main vectors of $L$. (V.) guyanensis in the Amazon (Ready et al., 1986; Scarpassa and Alencar, 2012; Brasil, 2017), other studies conducted in the region demonstrate the constant presence of this species in endemic areas for ATL (Lainson et al., 1981; Pinheiro et al., 2008). In the present study, the species was found in all collection environments, the most abundant after the forest edge (F100 and F400), the third most abundant species and the second placed in SISA/RANK. In endemic areas the presence of $\mathrm{Ny}$. umbratilis in intradomicile and peridomicile areas, can be misinterpreted as an adaptation of this species to these environments, but its presence is due to more attraction by the lights of the houses (Rangel and Lainson, 2009), its preferred habitat is the forest areas as confirmed by the collections of the present study. Three pools of the species were found infected with Leishmania DNA, which is in line with studies carried out in other regions of the Amazon and the Guiana shield (Ward and Fraiha, 1977; Ready et al., 1986; Souza et al., 2017).

The genus Psychodopygus was the one that presented the greatest representativeness in number of species in our collections (18.9\%), with a total of seven species: Ps. davisi, Ps. geniculatus (Mangabeira, 1941), Ps. squamiventris squamiventris, PS. hirsutus, Ps. paraensis (Costa Lima, 1941), Ps. corossoniensis and Ps. sq. maripaensis (Floch \& Abonnenc, 1946), all species had already been registered for the state. The genus has records in most of the Amazon region and has a greater number of species in the region than in the rest of the American continent (Gil et al., 2003). Psychodopygus davisi is considered one of the main vectors of protozoa that cause ATL, as it has characteristics that increase its vectorial capacity, such as being extremely anthropophilic (Castellón et al., 1994; Ferreira et al., 2014), and has been found infected with the main ATLcausing species in several states in the Amazon region and northern Brazil as: Le. (V.) braziliensis in Acre (Ávila et al., 2018), Rondônia (Grimaldi et al., 1991) and Pará (Souza et al. 2010), Le. (L.) amazonensis in Amazonas and Rondônia (Resadore et al., 2019), besides being also considered one of the potential vectors of Leishmania ( $V$.) naiffi in the Amazon region (Castellón et al., 1994; Gontijo and Carvalho, 2003; Gonçalves et al., 2016). This species has already been found as the most abundant in studies carried out in the Eastern Amazon (18.2\%) (Pereira Júnior et al., 2019), in our study, it was the fifth most collected species (6.0\%), and was found infected with DNA from Leishmania spp. in the intradomicile and forest areas of the Perimetral Norte rural settlement, which demonstrates that the species can be one of the probable active vectors in the area.

Other species with medical importance as Bi. flaviscutellata, $N y$. anduzei and Ny. antunesi, were found in the intradomicile and peridomicile areas, which shows an alert because finding females of these species close to the dwellings indicates the search for sources for blood meal making the risk of cases of ATL increase drastically (Tanure et al., 2015; Gonçalves et al., 2016). Bi. flaviscutellata was found in low density (2.1\%) in collections, corroborating with data from previous studies in the region (Souza et al., 2017), even in low density the species is of great medical importance as it is a proven vector of species of the subgenus Leishmania such as Le. (L.) amazonensis, and also Le. (V.) guyanensis, which can cause lesions in the region of the human mucosa that are similar to those caused by Le. $(V$.) braziliensis (Guerra et al., 2011), the species has already been found infected in the region of French Guiana (Fouque et al., 2007), region adjacent to the state of Amapá. Just as the finding of the $\mathrm{Ny}$. anduzei species is relevant, that is considered the secondary vector of Le.(V.) guyanensis in the state of Amazonas (Gonçalves et al., 2016; Chagas et al., 2018) and $N y$. antunesi which is identified as the putative vector of Le. (V.) lindenbergi in the state of Pará (Silveira et al., 2002), it is important to note that this species has developed household habits registered in studies in the state of Amazonas (Figueira et al., 2013) and in Colombia (Ferro et al., 2015), which, due to its highly anthropophilic habit, is one of the main vectors of ATL in the Amazon region.

There are few studies that describe the phlebotomine fauna in the easterm of the Amazon region, mainly in the state of Amapá. The Amazonian biome in the state has a great biodiversity and all the characteristics conducive to the reproduction of sand flies (vectors), mammals (reservoirs) and thus the maintenance of the cycle of tegumentary 
leishmaniasis. The present study demonstrated that in the Perimetral Norte Rural Settlement are found the three epidemiological patterns (Wild, Occupational / Leisure and Rural / Periurban) acting in synergy and resulting in the increase in cases of tegumentary leishmaniasis. Our data demonstrate that the presence of Leishmania vectors in the intra and peridomicile region may indicate serious risks for domestic animals and humans residing in the settlement. The present study demonstrates the importance of vector surveillance, which, by demonstrating the great diversity of sand flies and identifying those that are of medical and veterinary importance, especially in the intradomicile and peridomicile areas, as it indicates which vectors may be in the process of adapting to the domestic environment and so on. making vectors more competent, and thus contributing to the implementation of measures to control and prevent cases of ATL in rural areas.

\section{Acknowledgements}

We would like to thank the residents of the Perimetral Norte Rural Settlement, who allowed sample collection on their property. This study was financed in part by the Coordenação de Aperfeiçoamento de Pessoal de Nível Superior - Brasil (CAPES) [Finance Code 001]

\section{Conflict of interests}

The authors declare that there was no conflict of interests.

\section{Author contribution statement}

TSC, RMAF, GSS, RNPS contributed to the concept and design of the study, data analysis and interpretation, and manuscript preparation. MDGJ and CBP contributed to data collection and critical reviews, adding intellectual content to the manuscript.

\section{References}

Almeida, A.N.F., Nascimento, L.C.S., Sousa, E.S.M.M., Oliveira, A.J.D., Sena, M.G., Resende, B.M., Chaves, R.C.G., Garcez, L.M., 2020. Vigilância da leishmaniose cutânea em amostras clínicas: distribuição da Leishmania guyanensis no estado do Amapá, 2018*. Epidemiol. Serv. Saude. 29, e2018504. https://doi.org/10.5123/S1679-49742020000100007.

Amapá. Secretaria de Vigilância em Saúde, 2019. Boletim epidemiológico - situação epidemiológica da Leishmaniose Tegumentar no estado do Amapá: período de 2017 a junho de 2019. Secretaria de Vigilância em Saúde, Macapá.

Ávila, M.M., Brilhante, A.F., Souza, C.F., Bevilacqua, P.D., Galati, E.A.B., Brazil, R.P., 2018. Ecology, feeding and natural infection by Leishmania spp. of phlebotomine sand flies in an area of high incidence of American tegumentary leishmaniasis in the municipality of Rio Branco, Acre, Brazil. Parasit. Vectors. 11, 1-12. https://doi.org/10.1186/ s13071-018-2641-y.

Brasil, 2017. Manual de vigilância da Leishmaniose Tegumentar. Secretaria de Vigilância em Saúde, Brasília.

Brasil. Ministério da Saúde, 2021. Banco de dados do Sistema Único de Saúde - DATASUS. Informações de saúde, Sistema de Informação de Agravos de Notificação. Avaible in: http://tabnet.datasus.gov.br/ cgi/deftohtm.exe?sinannet/cnv/ltaap.def (acessed 04 August 2021)

Brazil, R.P., Andrade Filho, J.D., Falcão, A.L., 2000. Notes on phlebotomine sand flies (Diptera: psychodidae) from Amapá State, North Brazil. J. Am. Mosq. Control Assoc. 16, 40-41.
Brazil, R.P., Rodrigues, A.A.F., Andrade Filho, J.D., 2015. Sand fly vectors of Leishmania in the Americas - a mini review. Entomol. Ornithol. Herpetol. Curr. Res. 04, 4-7. https://doi.org/10.4172/2161-0983.1000144.

Carvalho, G.M.L., Rêgo, F.D., Tanure, A., Silva, A.C.P., Dias, T.A., Paz, G.F., Andrade Filho, J.D., 2017. Bloodmeal identification in field-collected sand flies from Casa Branca, Brazil, using the cytochrome b PCR method. J. Med. Entomol. 54, 1049-1054. https://doi.org/10.1093/ jme/tjx051.

Castellón, E.G., Arias, J.R., Freitas, R.A., Naiff, R.D., 1994. Os flebotomoníenos da Região Amazônica, estrada Manaus-Humaita, Estado do Amazonas, Brasil (Diptera:Psychodidae:Phlebotominae). Acta Amazon. 24, 91-102.

Chagas, E.C.D.S., Silva, A.S., Fé, N.F., Ferreira, L.S., Sampaio, V.D.S., Terrazas, W.C.M., Guerra, J.A.O., Souza, R.A.F., Silveira, H., Guerra, M.D.G.V.B., 2018. Composition of sand fly fauna (Diptera: Psychodidae) and detection of Leishmania DNA (Kinetoplastida: Trypanosomatidae) in different ecotopes from a rural settlement in the central Amazon, Brazil. Parasit. Vectors. 11, 1-10. https://doi.org/10.1186/s13071018-2743-6.

Ferreira, J.V.S., Santos, T.V., Santos, E.M., Gorayeb, I.S., 2014. Phlebotomine sand flies (Diptera: Psychodidae) in forest fragments of Belém metropolitan area, Pará State, Brazil, with considerations on vectors of American cutaneous leishmaniasis agents. Rev. Pan-Amazonica Saude. 5, 29-35. https://doi.org/10.5123/S2176-62232014000200004.

Ferro, C., López, M., Fuya, P., Lugo, L., Cordovez, J. M., González, C., 2015. Spatial distribution of sand fly vectors and eco-epidemiology of cutaneous leishmaniasis transmission in Colombia. PLoS One. 10, 1-16. https://doi.org/10.1371/journal.pone.0139391.

Figueira, E.A.G., Silva, G., Chagas, E.C.S., Shimabukuro, P.H.F., 2013. Phlebotomine sandflies (Diptera: Psychodidae) from Lábrea, state of Amazonas, Brazil, with a description of Evandromyia (Aldamyia) apurinan Shimabukuro, Figueira \& Silva, sp. nov. Mem. Inst. Oswaldo Cruz 108, 280-287. https://doi.org/10.1590/S007402762013000300004.

Filocreão, A.S.M., Silva, I.C., 2016. A política de assentamentos rurais no estado do amapá. PRACS. 9, 145. https://doi.org/10.18468/ pracs.2016v9n3.p145-171.

Folmer, O., Black, M., Hoeh, W., Lutz, R., Vrijenhoek, R., 1994. DNA primers for amplification of mitochondrial cytochrome c oxidase subunit I from diverse metazoan invertebrates. Mol. Mar. Biol. Biotechnol. 3, 294-299. https://doi.org/10.1371/journal.pone.0013102.

Forattini, O.P., 1959. Sôbre os flebótomos do território do Amapá, Brasil. Arq. Fac. Hig. Saude Publica Univ. Sao Paulo. 13, 159. https://doi. org/10.11606/issn.2358-792X.v13i1p159-164.

Fouque, F., Gaborit, P., Issaly, J., Carinci, R., Gantier, J., Ravel, C., Dedet, J., 2007. Phlebotomine sand flies (Diptera: Psychodidae) associated with changing patterns in the transmission of the human cutaneous leishmaniasis in French Guiana. Mem. Inst. Oswaldo Cruz 102, 35-40. https://doi.org/10.1590/S0074-02762007000100005.

Furtado, N.V.R., Galardo, A.K.R., Galardo, C.D., Firmino, V.C., Santos, T.V., 2016. Phlebotomines (Diptera: Psychodidae) in a hydroelectric system affected area from Northern Amazonian Brazil: further insights into the effects of environmental changes on vector ecology. J. Trop. Med. 2016, https://doi.org/10.1155/2016/9819723.

Galati, E. A. B., 2003. Classificação de Phlebotominae. In: Rangel, E.F., Lainson, R. (Eds.), Flebotomíneos do Brasil. Fiocruz, Rio de Janeiro, pp. 23-51.

Galati, E.A.B., 2017. Phlebotominae (Diptera, Psychodidae). Classificação, morfologia, terminologia e identificação de adultos. In: Universidade de São Paulo (Ed.), Apostila da disciplina HEP 5752-Bioecologia e Identificação Phlebotominae 2017. Programa Pós-Graduação em Saúde Pública, Faculdade de Saúde Pública, Universidade de São Paulo, São Paulo. Available in: www.fsp.usp.br/ egalati (accessed 5 September 2018). 
Galati, E.A.B., 2018. Phlebotominae (Diptera, Psychodidae): Classification, Morphology and Terminology of Adults and Identification of American Taxa. In: Rangel, E.F., Shaw, J.J. (Eds.), Brazilian Sand Flies. Springer International Publishing, Cham. https://doi.org/10.1007/978-3319-75544-1_2

Galati, E.A.B., 2019. Phlebotominae (Diptera, Psychodidae). Classificação, morfologia, terminologia e identificação de adultos. In: Universidade de São Paulo (Ed.), Apostila da disciplina HEP 5752-Bioecologia e Identificação Phlebotominae 2019. Programa Pós-Graduação em Saúde Pública, Faculdade de Saúde Pública, Universidade de São Paulo, São Paulo. Available in: www.fsp.usp.br/ egalati (accessed 4 July 2020).

Gil, L.H.S., Basano, S.A., Souza, A.A., Silva, M.G.S., Barata, I., Ishikawa, E.A., Camargo, L.M.A., Shaw, J.J., 2003. Recent observations on the sand fly (Diptera: Psychodidae) fauna of the State of Rondônia, Western Amazônia, Brazil: the importance of Psychdopygus davisi as a vector of zoonotic cutaneous leishmaniasis. Mem. Inst. Oswaldo Cruz. 98, 751-755. https://doi.org/10.1590/S0074-02762003000600007.

Gonçalves, R., Soares, D.C., Guimarães, R.J.P.S., Santos, W.S., Sousa, G.C.R., Chagas, A.P., Garcez, L.M., 2016. Diversity and ecology of sand flies (Psychodidae: Phlebotominae): foci of cutaneous leishmaniasis in Amazon Region, Brazil. Rev. Pan-Amazonica Saude. 7, 133-142. https://doi.org/10.5123/s2176-62232016000500015.

Gontijo, B., Carvalho, M.D.L.R., 2003. Leishmaniose tegumentar Americana. Rev. Soc. Bras. Med. Trop. 36, 71-80. https://doi.org/10.1590/S010442302006000600015.

Grimaldi, G., Momen, H., Naiff, R.D., McMahon-Pratt, D., Barrett, T.V., 1991. Characterization and classification of Leishmanial parasites from humans, wild mammals, and sand flies in the Amazon Region of Brazil. Am.J. Trop. Med. Hyg. 44, 645-661. https://doi.org/10.4269/ ajtmh.1991.44.645.

Guerra, J.A.O., Prestes, S.R., Silveira, H., Coelho, L.I.A.R.C., Gama, P., Moura, A., Amato, V., Barbosa, M.G.V., Ferreira, L.C.L., 2011. Mucosal Leishmaniasis caused by Leishmania (Viannia) braziliensis and Leishmania (Viannia) guyanensis in the Brazilian Amazon. PLoS Negl. Trop. Dis. 5, e980. https://doi.org/10.1371/journal.pntd.0000980.

Lainson, R., Shaw, J.J., Ready, P.D., Miles, M.A., Povoa, M., 1981. Leishmaniasis in Brazil: XVI. Isolation and identification of, Leishmania species from sandflies, wild mammals and man in north Pará State, with particular reference to L. braziliensis guyanensis causative agent of “pian-bois". Trans. R. Soc. Trop. Med. Hyg. 75 (4), 530-536. https:// doi.org/10.1016/0035-9203(81)90192-9.

Marcondes, C.B., 2007. A proposal of generic and subgeneric abbreviations for Phlebotomine sandflies (Diptera: Psychodidae: Phlebotominae) of the world. Entomol. News. 118, 351-356. https://doi.org/10.3157/0013872X(2007)118[351:APOGAS]2.0.CO;2.

Moreno, E.S., Sabioni, L.A., Seixas, M.M.M., Souza Filho, J.A., Marcelino, A.P., Shimabukuro, P.H.F., 2020. Evidence of a sylvatic enzootic cycle of leishmania infantum in the State of Amapá, Brazil. Rev. Soc. Bras. Med. Trop. 53, 13-15. https://doi.org/10.1590/0037-8682-0169-2019.

Oksanen, J., Blanchet, F.G., Kindt, R., Legendre, P., Minchin, P.R., O’Hara, R.B., Simpson, G.L., Solymos, P., Stevens, M.H.H., Wagner, H., 2017. Community Ecology Package "Vegan". Version 2.4-3. R Package, Vienna.

Pereira Júnior, A.M., Teles, C.B.G., Santos, A.P.A., Rodrigues, M.R., Marialva, E.F., Pessoa, F.A.C., Medeiros, J.F., 2015. Ecological aspects and molecular detection of Leishmania DNA Ross (Kinetoplastida: Trypanosomatidae) in phlebotomine sandflies (Diptera: Psychodidae) in terra firme and várzea environments in the Middle Solimões Region, Amazonas State, Brazil. Parasit. Vectors. 8, 1-11. https:// doi.org/10.1186/s13071-015-0789-2.

Pereira Júnior, A.M., Souza, A.B.N., Castro, T.S., Silva, M.S., Paulo, P.F.M., Ferreira, G.E.M., Medeiros, J.F., 2019. Diversity, natural infection and blood meal sources of phlebotomine sandflies (Diptera: Psychodidae) in the western Brazilian amazon. Mem. Inst. Oswaldo Cruz. 114, 1-9. https://doi.org/10.1590/0074-02760190170.

Perez, J. E., Ogusuku, E., Inga, R., Lopez, M., Monje, J., Paz, L., Nieto, E., Arevalo, J., Guerra, H., 1994. Natural Leishmania infection of lutzomyia spp. in Peru. Trans. R. Soc. Trop. Med. Hyg. 88 (2), 161-164. https:// doi.org/10.1016/0035-9203(94)90276-3.

Pinheiro, F.G., Luz, S.L.B., Franco, A.M.R., 2008. Infecção natural por tripanosomatídeos (Kinetoplastida: Trypanosomatidae) em Lutzomyia umbratilis (Diptera: Psychodidae) em áreas de leishmaniose tegumentar americana no Amazonas, Brasil. Acta Amaz. 38 (1), 165-172. https://doi.org/10.1590/S0044-59672008000100019

Pinto, I.S., Chagas, B.D., Rodrigues, A.A.F., Ferreira, A.L., Rezende, H.R., Bruno, R.V., Falqueto, A., Andrade-Filho, J.D., Galati, E.A.B., Shimabukuro, P.H.F., Brazil, R.P., Peixoto, A.A., 2015. DNA barcoding of neotropical sand flies (Diptera, Psychodidae, Phlebotominae): species identification and discovery within Brazil. PLoS One. 10, e0140636. https://doi.org/10.1371/journal.pone.0140636.

Rangel, E.F., Lainson, R., 2009. Proven and putative vectors of American cutaneous leishmaniasis in Brazil: aspects of their biology and vectorial competence. Mem. Inst. Oswaldo Cruz. 104, 937-954. https://doi.org/10.1590/S0074-02762009000700001.

Ready, P.D., Lainson, R., Shaw, J.J., Ward, R.D., 1986. The ecology of Lutzomyia umbratilis Ward \& Fraiha (Diptera: Psychodidae), the major vector to man of Leishmania braziliensis guyanensis in northeastern Amazonian brazil. Bull. Entomol. Res. 76, 21-40. https:// doi.org/10.1017/S0007485300015248.

Reale, S., Maxia, L., Vitale, F., Glorioso, N.S., Caracappa, S., Vesco, G., 1999. Detection of Leishmania infantum in dogs by PCR with lymph node aspirates and blood. J. Clin. Microbiol. 37, 2931-2935.

Resadore, F., Pereira Júnior, A.M., Carvalho, L.P.C., Santos, A.P.A., Teles, C.B.G., Medeiros, J. F., 2017. Phlebotomine sand fly composition (Diptera: Psychodidae) and putative vectors of American cutaneous leishmaniasis in Porto Velho municipality, Western Amazon, Brazil. J. Med. Entomol. 54, 798-803. https://doi.org/10.1093/jme/tjw233. Resadore, F., Pereira Júnior, A.M., Paulo, P.F.M., Gil, L.H.S., Rodrigues, M.M.D.S., Araújo, M.D.S., Julião, G.R., Medeiros, J.F., 2019. Composition and vertical stratification of phlebotomine sand fly fauna and the molecular detection of Leishmania in forested areas in Rondônia State municipalities, Western Amazon, Brazil. Vector Borne Zoonotic Dis. 19, 347-357. https://doi.org/10.1089/vbz.2018.2372.

Roberts, D.R., Hsi, B.P., 1979. An index of species abundance for use with mosquito surveillance data. Environ. Entomol. 8, 1007-1013. https://doi.org/10.1093/ee/8.6.1007.

Rosário, I.N.G., Andrade, A.J., Ligeiro, R., Ishak, R., Silva, I.M., 2017. Evaluating the adaptation process of sandfly fauna to anthropized environments in a Leishmaniasis transmission area in the Brazilian Amazon. J. Med. Entomol. 54, 450-459. https://doi.org/10.1093/ jme/tjw182.

Sambrook, J.W., Russell, D., 2012. Molecular Cloning: A Laboratory Manual, Cold Spring Harbor Laboratory Press, Cold Spring Harbor.

Saraiva, J. F., Nonato, R., Souto, P., Ferreira, A., 2011. Flebotomíneos (Diptera : Psychodidae) coletados em um assentamento rural no estado do Amapá, Brasil. Biota Amaz. 1 (1), 58-62.

Scarpassa, V.M., Alencar, R.B., 2012. Lutzomyia umbratilis, the main vector of Leishmania guyanensis, represents a novel species complex? PLoS One. 7, e37341. https://doi.org/10.1371/journal.pone.0037341.

Silva, N.S., Muniz, V.D., 2009. Epidemiologia da leishmaniose tegumentar americana no estado do Acre, Amazônia brasileira. Cad. Saude Publica. 25, 1325-1336. https://doi.org/10.1590/S0102-311X2009000600015.

Silva, Y.Y., Sales, K.G.D.S., Miranda, D.E.D.O., Figueredo, L.A., BrandãoFilho, S.P., Dantas-Torres, F., 2020. Detection of Leishmania DNA in 
sand flies (Diptera: Psychodidae) from a cutaneous Leishmaniasis outbreak area in Northeastern Brazil. J. Med. Entomol. 57, 529-533. https://doi.org/10.1093/jme/tjz189.

Silveira Neto, S., Nakano, O., Barbin, D., Vila Nova, N., 1976. Manual de ecologia dos insetos. Agronômica Ceres, São Paulo.

Silveira, F.T., Ishikawa, E.A.Y., Souza, A.A.A., Lainson, R., 2002. An outbreak of cutaneous leishmaniasis among soldiers in Belém, Pará State, Brazil, caused by Leishmania (Viannia) lindenbergi n. sp. Parasite 9, 43-50. https://doi.org/10.1051/parasite/200209143.

Souza, A., Barata, I., Silva, M., Lima, J., Martins, A., 2001. Contribuição à fauna de flebotomíneos (Diptera: Psychodidae) da Serra Navio, Amapá, Brasil. Rev. Soc. Bras. Med. Trop. 34 (Suppl 1), 53.

Souza, A.A.A., Silveira, F.T., Lainson, R., Barata, I.R., Silva, M.G.S., Lima, J.A.N., Pinheiro, M.S.B., Silva, F.M.M., Vasconcelos, L.S., Campos, M.B., Ishikawa, E.A.Y., 2010. The Phlebotominae fauna of Serra dos Carajás, Pará, Brazil, and its possible implication in the transmission of American tegumentary leishmaniasis. Rev. Pan-Amazonica Saude 1, 81-86. https://doi.org/10.5123/S2176-62232010000.

Souza, A.A.A., Santos, T.V., Jennings, Y.L.L., Ishikawa, E.A.Y., Barata, I.R., Silva, M.G.S., Lima, J.A.N., Shaw, J., Lainson, R., Silveira, F.T., 2016. Natural Leishmania (Viannia) spp. infections in phlebotomine sand flies (Diptera: Psychodidae) from the Brazilian Amazon region reveal new putative transmission cycles of American cutaneous leishmaniasis. Parasite 23, 22. https://doi.org/10.1051/parasite/2016022.

Souza, A.A.A., Barata, I.R., Silva, M.G.S., Lima, J.A.N., Jennings, Y.L.L., Ishikawa, E.A.Y., Prévot, G., Ginouves, M., Silveira, F.T., Shaw, J., Santos, T.V., 2017. Natural Leishmania( Viannia) infections of phlebotomines (Diptera: Psychodidae) indicate classical and alternative transmission cycles of American cutaneous leishmaniasis in the Guiana Shield, Brazil. Parasite. 24, 13. https://doi.org/10.1051/parasite/2017016.

Tadei, W.P., Rodrigues, I.B., Rafael, M.S., Sampaio, R.T.M., Mesquita, H.G., Pinheiro, V.C.S., Zequi, J.A.C., Roque, R.A., Santos, J.M.M., 2017. Adaptative processes, control measures, genetic background, and resilience of malaria vectors and environmental changes in the Amazon region. Hydrobiologia. 789, 179-196. https://doi.org/10.1007/ s10750-016-2960-y.
Tanure, A., Peixoto, J.C., Afonso, M.M.S., Duarte, R., Pinheiro, A.C. Coelho, S.V.B., Barata, R.A., 2015. Identification of sandflies (Diptera: Psychodidae: Phlebotominae) blood meals in an endemic Leishmaniasis area in Brazil. Rev. Inst. Med. Trop. São Paulo. 57, 321-324. https:// doi.org/10.1590/S0036-46652015000400008.

Tavares, J.P.N., 2014. Características da climatologia de Macapá-AP. Caminhos Geogr. 15, 138-151.

Teles, C.B.G., Santos, A.P.A., Freitas, R.A., Oliveira, A.F.J., Ogawa, G.M., Rodrigues, M.S., Pessoa, F.A.C., Medeiros, J.F., Camargo, L.M.A., 2016. Phlebotomine sandfly (Diptera: Psychodidae) diversity and their Leishmania DNA in a hot spot of American Cutaneous Leishmaniasis human cases along the Brazilian border with Peru and Bolivia. Mem. Inst. Oswaldo Cruz. 111, 423-432. https://doi. org/10.1590/0074-02760160054.

Trujillo, A.V., Reina, A.E.G., Orjuela, A.G., Suarez, E.P., Palomares, J.E., Alvarez, L.S.B., 2013. Seasonal variation and natural infection of Lutzomyia antunesi (Diptera: Psychodidae: Phlebotominae), an endemic species in the Orinoquia region of Colombia. Mem. Inst. Oswaldo Cruz. 108, 463-469. https://doi.org/10.1590/S00740276108042013011.

Valderrama, A., Tavares, M., Filho, J. D., 2014. Phylogeography of the Lutzomyia gomezi (Diptera: Phlebotominae) on the Panama Isthmus. Parasit. Vectors. 7, 9. https://doi.org/10.1186/1756-3305-7-9.

Ward, R.D., Fraiha, H., 1977. Lutzomyia umbratills, a new species of sand fly from Brazil (Diptera: psychodidae). J. Med. Entomol. 14, 313-317. https://doi.org/10.1093/jmedent/14.3.313.

World Health Organization - WHO, 2010. Control of the Leishmaniasis: Report of A Meeting of the WHO Expert Committee on the Control of Leishmaniases, Geneva, 22-26 March 2010. WHO, Geneva.

World Health Organization - WHO, 2021. Leishmaniasis Fact -Sheets. Available in https://www.who.int/news-room/fact-sheets/detail/ leishmaniasis (accessed 24 June 21).

Zivdari, M., Hejazi, S., Mirhendi, S., Jafari, R., Rastegar, H., Abtahi, S., 2018. Molecular identification of Leishmania parasites in sand flies (Diptera, Psychodidae) of an endemic foci in Poldokhtar, Iran. Adv. Biomed. Res. 7, 124. https://doi.org/10.4103/abr.abr_207_17. 